\title{
Water and nutrient productivity in melon crop by fertigation under subsurface drip irrigation and mulching in contrasting soils
}

\author{
Produtividade da água e de nutrientes em melão fertirrigado por gotejamento \\ subterrâneo sob mulching em diferentes tipos de solo
}

\author{
Rodrigo Otávio Câmara Monteiro ${ }^{\mathrm{I}}$ Rubens Duarte Coelho ${ }^{\mathrm{II}}$ \\ Priscylla Ferraz Câmara Monteiro ${ }^{\mathrm{II}}$
}

\section{ABSTRACT}

Cropping intensification and technical, economic and environmental issues require efficient application of production factors to maintain the soil productive capacity and produce good quality fruits and vegetables. The production factors, water and NPK nutrients, are the most frequent limiting factors to higher melon yields. The objective of the present study was to identify the influence of subsurface drip irrigation and mulching in a protected environment on the water and NPK nutrients productivity in melon cropped in two soil types: sandy loam and clay. The melon crop cultivated under environmental conditions with underground drip irrigation at $0.20 \mathrm{~m}$ depth, with mulching on sandy loam soil increased water and $\mathrm{N}, \mathrm{P}_{2} \mathrm{O}_{5}$ and $\mathrm{K}$ use efficiency.

Key words: water use efficiency, macronutrients, plastic cover.

\section{RESUMO}

A intensificação dos cultivos e os aspectos técnicoeconômicos e ambientais requerem maior eficiência concernente à aplicação dos fatores de produção, visando à manutenção da capacidade produtiva dos solos, à obtenção de hortaliças e de frutos de boa qualidade. Dentre os fatores de produção, a água e os macronutrientes NPK são os que limitam os rendimentos do melão com maior frequência. Este trabalho teve como objetivo identificar a influência do gotejamento subterrâneo e do mulching, em ambiente protegido, na produtividade da água e dos macronutrientes NPK, num cultivo de melão em dois tipos de solo: Latossolo Vermelho Amarelo (franco-arenoso) e Argissolo Vermelho (argiloso). A cultura do melão em ambiente protegido apresentou aumento de eficiência do uso da água e dos macronutrientes NPK com a utilização de irrigação por gotejamento subterrâneo a 0,20m de profundidade, com o uso do mulching e em solo franco-arenoso.

Palavras-chave: eficiência do uso da água, macronutrientes, cobertura plástica.

\section{INTRODUCTION}

Cropping intensification and technical, economic and environmental issues require efficient application of production factors to maintain the soil productive capacity and produce good quality fruits and vegetables (MONTEIRO et al., 2008b). The production factors, water and NPK nutrients, are the most frequent limiting factors to higher melon yields (AYOOLA \& ADENIYAN, 2006; PAULA et al., 2011). Thus irrigation and soil fertility monitoring is an essential criterion for the success of modern agriculture.

ROCKSTRÖM \& BARRON (2007), GEERTS \& RAES (2009) considered the concept of water productivity to be important and warned that due to the current development policy adopted in the world, the pressure on water resources for food production will increase, and water consumption will reach $5.600 \mathrm{~km}^{3}$ year ${ }^{-1}$ in 2050 , three times the amount of water used currently for irrigation worldwide. Given this scenario, water use efficiency is a requirement for irrigators (MONTEIRO et al., 2007; DIAS et al., 2012; MONTEIRO et al., 2008a; MONTEIRO et al., 2008b).

Applying plant nutrients by fertigation particularly with the drip irrigation is the most efficient way of nutrient application. Fertigation has the potential to supply a right mixture of water and nutrients to the root zone, and thus meeting plants'

\footnotetext{
Instituto Federal de Educação, Ciência e Tecnologia do Rio Grande do Sul (IFRS-BG), 95700-000, Bento Gonçalves, RS, Brasil. E-mail: rodrigo.monteiro@bento.ifrs.edu.br. Autor para correspondência

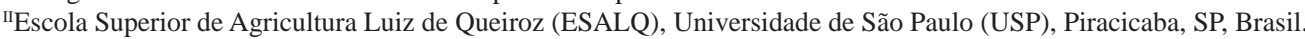

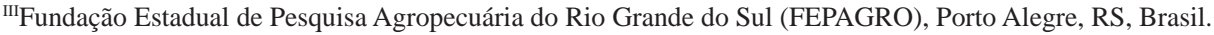
Received 07.16.12 Approved 05.25.13 Returned by the author 10.15.13 CR-2012-0546.R1
} 
water and nutrient requirements in the most efficient possible manner. Fertigation allows an accurate and uniform application of nutrients to the wetted area where most active roots are concentrated. Therefore, it is possible to dispense adequate nutrient quantity at an appropriate concentration to meet the crop demand during a growing season (BATTILANI, 2006).

The use of techniques such as drip irrigation and fertigation applied with subsurface drip and mulching may contribute to the water and nutrient productivity in melon production due reduction of the accumulation of water and fertilizer salts in the soil surface. It allows good water and nutrition to the melon crop, minimizing the effects of atmospheric evaporative demand, improving the quality and melon yield, according to better water and nutrients spatial distribution in the roots also reducing the environmental impact by excessive fertilization. Thus, the objective of the present study was to identify the influence of subsurface drip irrigation and mulching in a protected environment on the water and NPK nutrient productivity in melon cultivation in two soil types: sandy loam and clay.

\section{MATHERIAL AND METHODS}

This research was conducted in an experimental protected area of $330 \mathrm{~m}^{2}(22.0 \mathrm{~m} \mathrm{x}$ $15 \mathrm{~m})$, located in Piracicaba, Sao Paulo state, Brazil, at latitude $22^{\circ} 42^{\prime} 30^{\prime \prime} \mathrm{S}$, longitude $47^{\circ} 30^{\prime} 00^{\prime \prime}$ and $546 \mathrm{~m}$ altitude. The climate is Cwa according to Köppen, humid subtropical climate with dry winter and $1280 \mathrm{~mm}$ mean annual rainfall.

The experiment was conducted in greenhouses covered with transparent high density, $0.10 \mathrm{~mm}$ thick polyethylene film, treated against the action of ultraviolet rays. The greenhouse contained 112 500L boxes distributed in 8 rows, 4 rows of boxes filled with sandy loam soil and four rows of boxes filled with clay soil.

There were three research variables: subsurface drip depth (3 levels), soil cover (two levels) and soil (two levels). The drip depths were the soil surface of the soil, $0.20 \mathrm{~m}$ and $0.40 \mathrm{~m}$, soil cover levels were mulching and bare soil, and the soils, sandy loam (SLS) and clay soil (CS). The experiment was conducted in a randomized block design with four blocks each, with the treatments arranged in a $3 \times 2 \times 2$ factorial (12 treatments), with the combination of variables as plastic mulching, drip depth and type of soil, totaling 48 experimental plots. Each plot consisted of two plants, each plant being placed in a cement box, totaling therefore 96 plants (boxes).
The plastic film used in the experiment, was made in Israel and has the following specifications: double-sided (silver on the upper side and black on the underside), 25 micron thick, $28 \mathrm{MPa}$ stress fracture toughness, $400 \%$ elongation up to fracture, photosynthetically active radiation and less than $1 \%$ reflection of photosynthetically, active radiation transmission greater than $25 \%$.

The crop used in this study was the melon (Cucumis melo L.) lacey, hybrid, Bonus II, conducted under staking. The seeds were sown in 128-cell trays, and 21 days after sowing (DAS), when plants had two true leaves, they were transplanted to the greenhouse boxes.

The irrigation system used in the experiment was localized, through a drip composed of four derivation lines of $16 \mathrm{~mm}$ nominal diameter polyethylene and the side lines were of the same material and diameter. The drippers were selfcompensating of $4 \mathrm{~L} \mathrm{~h}^{-1}$ flow rate, operated at a $150 \mathrm{kPa}$ operating pressure and for treatments with subsurface drip, emitters were buried in "spaghetti”, placed in a 1 "diameter PVC pipe, buried in the soil at depths of 0.20 and $0.40 \mathrm{~m}$. Treatments related to these depths had their drip buried after $27^{\text {th }}$ DAT. Fertigation was carried out weekly (Table 1), as suggested by SOUSA et al. (1997), respecting the crop uptake and soil chemical analyses, who were very similar in both soil. The fertilizer was applied by direct suction from a 500L tank.

The water productivity (PA), $\mathrm{kg} \mathrm{m}^{-3}$ in both soils was determined by the relationship between the fresh fruit yield (MVF), in $\mathrm{kg}^{-1}$ plant, and the quantity of water (L) applied in the treatments, or by the estimate of water transpired for boxes without "mulching" (ETc), or the amount of water transpired for boxes with mulching ( $\mathrm{T}$ ), according to the equations (1):

$$
\begin{aligned}
& P A=\frac{M T F}{L} \text { ou } P A_{\text {without mulching }}=\frac{M T F}{E T_{c}} \text { ou } \\
& P A_{\text {mulching }}=\frac{M T F}{T}
\end{aligned}
$$

where:

PA - water productivity, $\mathrm{kg} \mathrm{m}^{-3}$;

MVF - fresh fruit mass productivity, kg plant ${ }^{-1}$;

$\mathrm{L}$ - water volume applied by irrigation, $\mathrm{m}^{3}$ plant $^{-1}$;

ETc - crop evapotranspiration without mulching, $\mathrm{m}^{3}$ plant $^{-1}$;

$\mathrm{T}$ - crop transpiration under mulching, em $\mathrm{m}^{3}$ plant $^{-1}$.

The Penman-Monteith - FAO standard model (ALLEN et al., 1998) was used to estimate 
Table 1 - Percentage of $\mathrm{N}, \mathrm{P}_{2} \mathrm{O}_{5}$ and $\mathrm{K}$ nutrients in a 7-day interval recommended for melons and total fertilizer applied through irrigation water to 112 plants in the experimental area $\left(112 \mathrm{~m}^{2}\right)$ - Piracicaba, 2005-2006

\begin{tabular}{|c|c|c|c|c|c|c|c|}
\hline \multirow[b]{2}{*}{$\begin{array}{l}\text { Days after } \\
\text { transplanting } \\
\text { (DAP) }\end{array}$} & \multirow[b]{2}{*}{$\mathrm{N}$} & \multirow[b]{2}{*}{$\mathrm{P}_{2} \mathrm{O}_{5}$} & \multirow[b]{2}{*}{ K } & \multicolumn{4}{|c|}{ 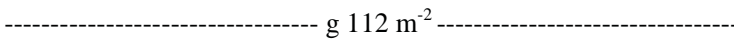 } \\
\hline & & & & $\begin{array}{l}\text { Ammonium } \\
\text { sulfate } \\
\left(\mathrm{NH}_{4}\right)_{2} \mathrm{SO}_{4}\end{array}$ & $\begin{array}{c}\text { Urea } \\
\left(\mathrm{NH}_{2}\right)_{2} \mathrm{CO}\end{array}$ & $\begin{array}{c}\text { Phosphoric } \\
\text { acid } \\
\mathrm{H}_{3} \mathrm{PO}_{4}\end{array}$ & $\begin{array}{c}\begin{array}{c}\text { Potassium } \\
\text { chloride }\end{array} \\
\mathrm{KCl}\end{array}$ \\
\hline $1-8$ & 1.0 & 1.2 & 0.3 & 77.28 & - & 79.88 & 17.55 \\
\hline $9-16$ & 1.3 & 1.2 & 0.6 & 100.24 & - & 79.88 & 34.91 \\
\hline $17-24$ & 2.3 & 2,8 & 1.6 & 177.52 & - & 186.38 & 93.15 \\
\hline $25-32$ & 6.0 & 7.2 & 3.8 & 154.56 & 137.39 & 479.28 & 221.39 \\
\hline $33-40$ & 10.6 & 10.0 & 7.8 & - & 364.12 & 665.66 & 454.35 \\
\hline $41-48$ & 16.6 & 14.0 & 15.6 & - & 570.20 & 931.92 & 908.51 \\
\hline $49-56$ & 28.5 & 18.0 & 18.2 & - & 978.88 & 1198.19 & 1059.89 \\
\hline $57-64$ & 15.9 & 17.2 & 20.8 & - & 546.06 & 1144.94 & 1211.47 \\
\hline $65-72$ & 7.9 & 10.8 & 19.5 & - & 271.29 & 718.91 & 1135.68 \\
\hline $73-80$ & 6.6 & 5.0 & 9.1 & - & 226.74 & 332.83 & 529.95 \\
\hline $81-88$ & 3.3 & 2.8 & 2.6 & - & 113.24 & 186.38 & 151.39 \\
\hline \multicolumn{5}{|c|}{ Total mass element (g) plant ${ }^{-1}$} & $\begin{array}{l}\text { 13,79 g N } \\
\text { plant }^{-1}\end{array}$ & $\begin{array}{l}\text { 29,48 g P } \\
\text { plant }^{-1}\end{array}$ & $\begin{array}{l}\text { 31,14 g K } \\
\text { plant }^{-1}\end{array}$ \\
\hline
\end{tabular}

the ETo using $0.063 \mathrm{kPa}^{\circ} \mathrm{C}^{-1}$ for the psychrometric constant. To estimate the ETo in the protected environment, from external environment ETo, eq. (2), was used by Blanco and FOLEGATTI (1998) model from an experiment carried out in the in the same area. The Kc values of the melon crop were adopted according to eq. 3 by SILVA et al. (2004), who worked with the same cultivar and adopted the same management and in the same experimental area.

$y=(0,6797 x)+0,4727 \quad r^{2}=0,91$

where:

$y$ - reference evapotranspiration (ETo) estimated for the protected environment, $\mathrm{mm}_{\text {day }}{ }^{-1}$;

$x$ - external environment ETo, em mm day ${ }^{-1}$.

$K_{\mathrm{c}}=-0,0003 \mathrm{DA} T^{2}+0,0431$ DAT $-0,4184 r^{2}=0,76$ (3)

where:

DAT - days after transplanting.

The nutrient productivity or NPK nutrients use efficiency in $\mathrm{kg}$ of fresh fruit mass (MVF) per $\mathrm{kg}$ of fertilizer was applied, in both sandy loam (SLS) and clay soil (CS) and it was determined the ratio between the fresh fruit yield (MVF), kg ha-1, and the amount of nutrients applied $\left(\mathrm{N}, \mathrm{P}_{2} \mathrm{O}_{5}\right.$ or $\mathrm{K}$ ) in the fertigation, $\mathrm{kg}_{\text {plant }}{ }^{-1}$ according to the equation:

$$
P N_{\text {Nou } P_{2} O_{5} \text { ou K }}=\frac{M V F}{Q_{\text {Nor } P_{2} O_{5} \text { ou } K}}
$$

where:

$\mathrm{PN}$ - nitrogen use efficiency $(\mathrm{N})$, or phosphorus $\left(\mathrm{P}_{2} \mathrm{O}_{5}\right)$ or potassium $(\mathrm{K})$, $\mathrm{kg}$ fresh fruit mass per $\mathrm{kg}^{-1}$ of nutrient applied;

MVF - fresh fruit mass productivity, $\mathrm{kg}$ plant $^{-1}$;

$\mathrm{Q}$ - amount of nitrogen $(\mathrm{N})$, or phosphorus $\left(\mathrm{P}_{2} \mathrm{O}_{5}\right)$ or potassium $(\mathrm{K})$ by fertigation applied during crop cycle, kg plant ${ }^{-1}$.

\section{RESULTS AND DISCUSSION}

The amount of melon (fresh fruit mass) produced per water unit applied ranged from 12.18 to $21.52 \mathrm{~kg} \mathrm{~m}^{-3}\left(\mathrm{PA}_{1}\right.$ e $\mathrm{PA}_{2}$ ) (Table 2 and 3). VASQUEZ et al. (2005), used the same hybrid PA values ranging from 1.98 to $15.87 \mathrm{~kg} \mathrm{~m}^{-3}$.

ThelowestPAvalueswerefoundinbothsoils without mulching. The crop with underground drip at $0.20 \mathrm{~m}$ resulted in better PA when compared to surface and $0.40 \mathrm{~m}$ drip irrigation. This was due to water application next to the roots and thus reduced loss by evaporation (drip on the surface) or by deep percolation ( 0.40 drip $\mathrm{m}$ ), in addition to the effect of increased retention and better moisture distribution provided by mulching, which can help to maximize the efficient use of water (SAMPAIO \& ARAÚJO, 2001; SAMPAIO et al., 1999; PHENE et al., 1992; HANSON et al., 1994). It was also observed that the 
Table 2 - Water productivity mean values in $\mathrm{kg}$ of fresh fruit mass (MVF) per $\mathrm{m}^{3}$ of water applied (175.2 $\left.\mathrm{mm}\right)\left(\mathrm{PA}_{1}\right)$, or from evapotranspiration without mulching treatments $(187.2 \mathrm{~mm})$, or from transpiration in mulching treatments $(160.2 \mathrm{~mm})\left(\mathrm{PA}_{2}\right) ; \mathrm{N}$ $\left(\mathrm{P}_{\mathrm{N}}\right), \mathrm{P}\left(\mathrm{P}_{\mathrm{P} 205}\right)$ and $\mathrm{K}\left(\mathrm{P}_{\mathrm{K}}\right)$ efficiency mean values in $\mathrm{kg}$ of fresh fruit mass (MVF) per kg of nutrient applied - Piracicaba, SP, 2005-2006

\begin{tabular}{|c|c|c|c|c|c|}
\hline \multirow[t]{2}{*}{$\begin{array}{l}\text { Source of } \\
\text { variation }\end{array}$} & $\mathrm{PA}_{1}$ & $\mathrm{PA}_{2}$ & $\mathrm{P}_{\mathrm{N}}$ & $\mathrm{P}_{\mathrm{P} 2 \mathrm{O} 5}$ & $\mathrm{P}_{\mathrm{K}}$ \\
\hline & \multicolumn{2}{|c|}{$\begin{array}{c}\text { (kg MVF per } \mathrm{m}^{3} \text { of water applied or mm } \\
\text { evapotranspirated) }\end{array}$} & ---.-. & $\mathrm{kg}$ of nut & . \\
\hline \multicolumn{6}{|l|}{ Type of Soil } \\
\hline Sandy loam & $19.22^{\mathrm{b}}$ & $17.77^{\mathrm{b}}$ & $241.48^{\mathrm{b}}$ & $108.86^{\mathrm{b}}$ & $103.06^{\mathrm{b}}$ \\
\hline Clay & $17.27^{\mathrm{a}}$ & $15.93^{\mathrm{a}}$ & $215.47^{\mathrm{a}}$ & $97.14^{\mathrm{a}}$ & $91.96^{\mathrm{a}}$ \\
\hline \multicolumn{6}{|c|}{ Irrigation drip depth } \\
\hline $0.0 \mathrm{~m}$ & $17.65^{\mathrm{a}}$ & $16.29^{\mathrm{a}}$ & $220.98^{\mathrm{a}}$ & $99.62^{\mathrm{a}}$ & $94.31^{\mathrm{a}}$ \\
\hline $0.20 \mathrm{~m}$ & $19.41^{b}$ & $18.52^{b}$ & $235.01^{\mathrm{a}}$ & $105.95^{\mathrm{a}}$ & $100.30^{\mathrm{a}}$ \\
\hline $0.40 \mathrm{~m}$ & $18.32^{\mathrm{a}}$ & $16.92^{\mathrm{a}}$ & $229.45^{\mathrm{a}}$ & $103.44^{\mathrm{a}}$ & $97.92^{\mathrm{a}}$ \\
\hline \multicolumn{6}{|l|}{ Mulching } \\
\hline - & $15.14^{\mathrm{a}}$ & $14.17^{\mathrm{a}}$ & $199.59^{\mathrm{a}}$ & $89.98^{\mathrm{a}}$ & $85.18^{\mathrm{a}}$ \\
\hline+ & $21.35^{\mathrm{b}}$ & $19.52^{\mathrm{b}}$ & $257.37^{\mathrm{b}}$ & $116.02^{\mathrm{b}}$ & $109.84^{\mathrm{b}}$ \\
\hline
\end{tabular}

Means followed by the same letter in the column did not differ from each other, Tukey test, $\mathrm{p}<0.05^{*}$ or $\mathrm{p}<0.01^{* *}$

The sign "-" means no, the "+" presence

use of emitters buried at $0.20 \mathrm{~m}$ resulted in increased PA. ANTUNEZ et al. (2009), who also works with melon, reported improved efficiency of water use in subsurface drip to $0.20 \mathrm{~m}$, compared to surface drip and surface irrigation. Higher PA values was reported for many crops under subsurface drip irrigation (HEBBAR et al., 2004; PATEL \& RAJPUT, 2007; THOMPSON et al., 2003; ONDER et al., 2005). BADR (2007) found that subsurface drip irrigation increased downward the movement of water and nutrient on the account of horizontal movement and thus, l decreased moisture loss by evaporation, saving more water and nutrient in the subsurface soil layers for plant use.
The mulching allowed a productivity water $\left(\mathrm{PA}_{1}\right.$ and $\left.\mathrm{PA}_{2}\right)$ 41.1\% higher $\left(21.35 \mathrm{~kg} \mathrm{~m}^{-3}\right.$ ) compared to the no mulching that was $15.14 \mathrm{~kg} \mathrm{~m}^{-3}$ (Table 2). CASTILLA et al. (1998) found the highest water use efficiency (PA) was obtained in the mulched melons averaging $19.0 \mathrm{~kg}$ marketable fruit per cubic meter of dripapplied water. Interestingly, the PA gain on the ground, with mulching, was much higher in the CS (65.4\%) than that obtained in the SLS (22.6\%) (Table 3). SEYFI and RASHIDI (2007) in Iran found the drip irrigation + plastic mulching treatment to be more effective irrigation method in improving PA and increasing Cantaloupe yield. The sandy loam soil (SLS) allowed a water use efficiency $\left(\mathrm{PA}_{1}\right) \quad 32.7 \%$ higher $\left(17.27 \mathrm{~kg} \mathrm{~m}^{-3}\right)$

Table 3 - Unfolding analysis of "soil x plastic" interaction to water productivity mean values in $\mathrm{kg}$ of fresh fruit mass (MVF) per $\mathrm{m}^{3}$ of water applied $(175.2 \mathrm{~mm})\left(\mathrm{PA}_{1}\right)$, or from evapotranspiration in no mulching treatments $(187.2 \mathrm{~mm})$, or from transpiration in mulching treatments $(160.2 \mathrm{~mm})\left(\mathrm{PA}_{2}\right) ; \mathrm{N}\left(\mathrm{P}_{\mathrm{N}}\right), \mathrm{P}\left(\mathrm{P}_{\mathrm{P} 205}\right)$ and $\mathrm{K}\left(\mathrm{P}_{\mathrm{K}}\right)$ efficiency mean values in kg of fresh fruit mass (MVF) per kg of nutrient applied - Piracicaba, SP, 2005-2006.

\begin{tabular}{|c|c|c|c|c|c|}
\hline \multirow[t]{2}{*}{$\begin{array}{l}\text { Source of } \\
\text { variation }\end{array}$} & $\mathrm{PA}_{1}$ & $\mathrm{PA}_{2}$ & $\mathrm{P}_{\mathrm{N}}$ & $\mathrm{P}_{\mathrm{P} 2 \mathrm{O5}}$ & $\mathrm{P}_{\mathrm{K}}$ \\
\hline & \multicolumn{2}{|c|}{$\begin{array}{l}\text { (kg MVF per } \mathrm{m}^{3} \text { of water applied or mm } \\
\text { evapotranspirated) }\end{array}$} & --- & er kg of nu & \\
\hline \multicolumn{6}{|l|}{ No mulching } \\
\hline Sandy loam & $17.27^{\mathrm{b}}$ & $16.16^{\mathrm{b}}$ & $227.65^{\mathrm{b}}$ & $102.63^{\mathrm{b}}$ & $97.16^{\mathrm{b}}$ \\
\hline Clay & $13.01^{\mathrm{a}}$ & $12.18^{\mathrm{a}}$ & $171.53^{\mathrm{a}}$ & $77.33^{\mathrm{a}}$ & $73.21^{\mathrm{a}}$ \\
\hline \multicolumn{6}{|l|}{ Mulching } \\
\hline Sandy loam & $21.18^{\mathrm{a}}$ & $19.37^{\mathrm{a}}$ & $255.32^{\mathrm{a}}$ & $115.10^{\mathrm{a}}$ & $108.96^{\mathrm{a}}$ \\
\hline Clay & $21.52^{\mathrm{a}}$ & $19.68^{\mathrm{a}}$ & $259.42^{\mathrm{a}}$ & $116.95^{\mathrm{a}}$ & $110.71^{\mathrm{a}}$ \\
\hline
\end{tabular}

Ciência Rural, v.44, n.1, jan, 2014. 
compared to the clay soil (CS) that was of $13.01 \mathrm{~kg} \mathrm{~m}^{-3}$ (Table 3).

The amount of melon (fruit fresh matter) produced per unit of nutrient applied by fertigation ranged from 171.53 to $259.42 \mathrm{~kg} \mathrm{~kg}^{-1} \mathrm{~N}, 77.33$ to $116.95 \mathrm{~kg} \mathrm{~kg}^{-1} \mathrm{P}_{2} \mathrm{O}_{5}$ and 73.21 to $110.71 \mathrm{~kg} \mathrm{~kg}^{-1} \mathrm{~K}$ (Table 3). The NPK macronutrients analyzed in the SLS allowed an average water use efficiency of $32.71 \%$ higher than in CS (Table 3). The addition of $\mathrm{P}_{\mathrm{N}}, \mathrm{P}_{\mathrm{P} 205}$ and $\mathrm{P}_{\mathrm{K}}$ to $\mathrm{CS}$, with the adoption of mulching, was much higher (51\% average for the three nutrients analyzed) than that obtained in the SLS (12\%) (Table 3). The plastic cover on the ground probably prevented the atmospheric evaporative demand from interfering with the distribution of water and ions in the wet bulb, while the depth of $0.20 \mathrm{~m}$ allowed drip application of water and nutrients close to the root absorption zone, providing thus better melon production due to better water and nutrient spatial distribution in the root systems (SAMPAIO et al., 1999).

With or without mulching in both soils, there was no effect of drip depth on the macronutrient use efficiency (Table 2). The use of mulching in both soils showed greater melon production by applied fertilizer $\left(257.37 \mathrm{~kg} \mathrm{~N} \mathrm{~kg}^{-1}\right.$; $116.02 \mathrm{~kg}^{\mathrm{P}} 2 \mathrm{O} 5 \mathrm{~kg}^{-1}$, $\left.109.89 \mathrm{~kg} \mathrm{~kg}^{-1} \mathrm{~K}\right)$ compared to the bare soil $(199.59 \mathrm{~kg}$ $\mathrm{kg}^{-1} \mathrm{~N}$, 89.98 $\mathrm{kg} \mathrm{kg}^{-1} \mathrm{P} 2 \mathrm{O} 5,85.18 \mathrm{~kg} \mathrm{~kg}^{-1} \mathrm{~K}$ ) (Table 2).

\section{CONCLUSION}

The subsurface drip irrigation at $0.20 \mathrm{~m}$ depth and mulching on sandy loam soil increased water and $\mathrm{N}, \mathrm{P}_{2} \mathrm{O}_{5}$ and $\mathrm{K}$ use efficiency on melon crop under protected environmental conditions.

\section{ACKNOWLEDGMENTS}

The authors thank Conselho Nacional de
Desenvolvimento Científico e Tecnológico (CNPq)
and Coordenação de Aperfeiçoamento de Pessoal de Nível
Superior (CAPES) for financial support.

\section{REFERENCES}

ALLEN, R.G. et al.. Crop evapotranspiration: guidelines for computing crop water requeriments. Rome: FAO, 1998. 328p. (FAO. Irrigation and Drainage Paper, 56).

ANTUNEZ, A. et al. Impact of surface and subsurface drip irrigation on yield and quality of 'Honey Dew' melon. In: INTERNATIONAL SYMPOSIUM ON IRRIGATION OF HORTICULTURAL CROPS, 6., 2009, Leuven. Proceedings... Leuven: ISHS Acta Horticulturae, 2009. p889.

AYOOLA, O.T.; ADENIYAN, O.N. Influence of poultry manure and NPK fertilizer on yield and yield components of crops under different cropping systems in south west Nigeria. African Journal of Biotechnology, v.5, n.15, p.1386-1392, 2006.

BADR, M.A. Spatial distribution of water and nutrients in root zone under surface and subsurface drip irrigation ansd Cataloupe yield. World Journal of Agricultural Sciences, v.3, n.6, p.747-756. 2007.

BATTILANI, A.; SOLIMANDO, D. Yield, quality and nitrogen use efficiency of fertigated watermelon. Acta Horticulturae, v.700, p.85-90, 2006.

BLANCO, F.F.; FOLEGATTI, M.V. Estimativa da evapotranspiração em estufa plástica utilizando dados meteorológicos externos. In: BALBUENA, R.H. et al. (Ed.). Avances em el manejo delsuelo y agua em laingeniería rural latinoamericana. La Plata: UNLP, 1998. p.361-366.

CASTILLA, N. et al. Greenhouse melon response to plastic mulch. In: INTERNATIONAL SYMPOSIUM ON WATER QUALITY \& QUANTITY-GREENHOUSE: ISHS Acta Horticulturae 458: 1998. p.263-268. Available from: <http://www. actahort.org/books/458/458_33.htm>. Accessed: out. 10, 2009.

DIAS, N. da S. et al. Produção de melão rendilhado em sistema hidropônico com rejeito da dessalinização de água em solução nutritiva. Revista Brasileira de Engenharia Agrícola e Ambiental, v.14, n.7, p.755-761, 2012.

GEERTS, S.; RAES, D. Deficit irrigation as an on-farm strategy to maximize crop water productivity in dry áreas. Agricultural Water Management, v.96, n.9, p.1275-1284, 2009.

HANSON, B. et al. Drip irrigation for row crops. Davis: University of California, 1994. 159p. (Water Management Series Publication, 93-105).

HEBBAR, S.S. et al. Studies on NPK drip fertigation in field grown tomato (Lycopersicon esculentum Mill.). European Jornal of Agronomy, v.21, n.1, p.117-127, 2004.

MONTEIRO, R.O.C. et al. Aspectos produtivos e de qualidade do melão sob gotejo subterrâneo e "mulching” plástico. Acta Scientiarum Agronomy, v.29, n.4, p.453-457, 2007.

MONTEIRO, R.O.C. et al. Net melon performance as affectedbythedripirrigationdepthandmulching. Horticultura Brasileira, v.26, n.4, p.447-451, 2008a.

MONTEIRO, R.O.C. et al. Eficiência do uso da água e nitrogênio na produção de melão. Revista Irriga, v.13, n.3, p.367-377, 2008b.

PATEL, N.; RAJPUT, T.B.S. Effect of drip tape placement depth and irrigation level on yield of potato. Agricultural Water Management, v.88, n.1, p.209-223, 2007.

PAULA, J.A. de A. et al. Metodologia para determinação das necessidades nutricionais de melão e melancia. Revista Brasileira de Engenharia Agrícola e Ambiental, v.15, n.9, p.911-916, 2011.

PHENE, C.J. et al. Maximizing water use efficiency with subsurface drip irrigation. St. Joseph: ASAE, 1992. 209p.

ROCKSTRÖM, J.; BARRON, J. Water productivity in rainfed systems: overview of challenges and analysis of opportunities in water scarcity prone savannahs. Irrigation Science, v.25, n.3, p.299-311, 2007. 
SAMPAIO, R.A.; ARAÚJO, W.F. Importância da cobertura plástica do solo sobre o cultivo de hortaliças. Agropecuária Técnica, Areia, v. 22, n. 1, p. 1-12, 2001.

SAMPAIO, R. A.; et al. Resposta do tomateiro à fertirrigação potássica e cobertura plástica do solo. Pesquisa Agropecuária Brasileira, Brasília, v. 34, p. 21-30, 1999.

SEYFI, K. \& RASHIDI, M. Effect of Drip Irrigation and Plastic Mulch on Crop Yield and Yield Components of Cantaloupe. International Journal of Agriculture and Biology, Leuven, v. 02, p. 247-249, 2007.

SILVA, T. J. A. da; et al. Coeficiente de cultivo (Kc) do meloeiro tipo rendilhado cultivado em ambiente protegido. Irriga, Botucatu, v.9, n.1, p.72-81, 2004.
SOUSA, V. F.; et al. Produtividade e qualidade de dez cultivares de melão (Cucumis melo L.) sob regime de fertirrigação por gotejamento. In: CONGRESSO BRASILEIRO DE OLERICULTURA, 1997, Manaus. Proceedings... Manaus: Horticultura Brasileira, v.15, Suplemento, 1997. p.294-298.

THOMPSON, T. L.; et al. Fertigation frequency for subsurface drip-irrigated broccoli. Soil Science Society American Journal, v.67, n.1, p.910-918. 2003

ONDER, S.; et al. Different irrigation methods and water stress effects on potato yield and yield components. Agricultural Water Management, v.73, n.1, p.73-86, 2005.

VÁSQUEZ, M. A. N.; et al.Qualidade pós-colheita de frutos de meloeiro fertirrigado com diferentes doses de potássio e lâminas de irrigação. Revista Brasileira de Engenharia Agrícola e Ambiental, Jaboticabal, v.9, n.2, p.199-204, 2005. 